University of Nebraska - Lincoln

DigitalCommons@University of Nebraska - Lincoln

West Central Research and Extension Center, North Platte

Agricultural Research Division of IANR

2009

\title{
The Effect of Adjuvants, Pesticide Formulation, and Spray Nozzle Tips on Spray Droplet Size
}

\author{
Robert N. Klein \\ University of Nebraska-Lincoln, robert.klein@unl.edu \\ Jeffrey A. Golus \\ University of Nebraska - Lincoln, jeff.golus@unl.edu \\ Kelli L. Nelms \\ University of Nebraska - Lincoln
}

Follow this and additional works at: https://digitalcommons.unl.edu/westcentresext

Part of the Agriculture Commons, Ecology and Evolutionary Biology Commons, and the Plant Sciences Commons

Klein, Robert N.; Golus, Jeffrey A.; and Nelms, Kelli L., "The Effect of Adjuvants, Pesticide Formulation, and Spray Nozzle Tips on Spray Droplet Size" (2009). West Central Research and Extension Center, North Platte. 97.

https://digitalcommons.unl.edu/westcentresext/97

This Article is brought to you for free and open access by the Agricultural Research Division of IANR at DigitalCommons@University of Nebraska - Lincoln. It has been accepted for inclusion in West Central Research and Extension Center, North Platte by an authorized administrator of DigitalCommons@University of Nebraska Lincoln. 


\title{
The Effect of Adjuvants, Pesticide Formulation, and Spray Nozzle Tips on Spray Droplet Size
}

\begin{abstract}
Many factors, including adjuvants, pesticide formulations, and nozzle tips, affect spray droplet size. It is important to understand these factors as spray droplet size affects both drift and efficacy of pesticides, which is a main concern with pesticide application. A laser particle analyzer was used to determine the spray droplet size and distributions of a range of formulations sprayed through several types of nozzle tips. Nozzles included were extended range flat fan sizes 11003 and 11005 (Spraying Systems XR), air induction flat fan sizes 11005 and 11004 (Al), air induction extended range flat fan size 11005 (AIXR), preorifice flat fan size 11005 (TT), and a second preorifice flat fan size 2.5 (TF). Several deposition/ retention adjuvants were studied, including Array, Interlock, In-Place, and Thrust. Another study looked at diflufenzopyr + dicamba (Status, BASF) in combination with several adjuvants. Also, three fungicides were evaluated at differing spray volumes. Results indicated that the droplet size of some nozzle tips is more affected than others by changes in the contents of the spray solution.
\end{abstract}

KEYWORDS: spray droplet size, spray particle distribution, adjuvant

\section{Introduction}

Most spray nozzle tips used in the application of pesticides produce a distribution of droplet sizes, which refers to the diameter of an individual spray droplet. Spray nozzle classification by droplet spectrum in the United States was developed and approved by the American Society of Agricultural Engineers [1]. This Standard defines droplet spectrum categories for the classification of spray nozzles, relative to specified reference fan nozzles discharging spray into static air so that no stream of air enhances atomization. This provides a means for relative nozzle comparisons based on droplet size only. Other spray drift and application efficacy factors (e.g., droplet discharge trajectory, height, and velocity; air bubble inclusion; droplet evaporation; and force of impact on target) are not addressed. The Standard is based on spraying water through the reference nozzles and nozzles to be classified. However, spray liquid properties affect droplet sizes and should be considered by the end user. Reference flow rate and operating pressure are specified for each reference nozzle because droplet size spectra from pressure atomizers are affected by these parameters (Table 1).

A reference graph for nozzle classification is established from droplet size spectra measurements obtained for all of the reference nozzles. The droplet diameter in microns is plotted versus the cumulative spray volume (fraction or percent) for the five reference nozzles as a reference graph. An example refer-

TABLE 1-Classification category threshold values for flat spray nozzles.

\begin{tabular}{lccccc}
\hline & $\begin{array}{c}\text { Classification category } \\
\text { threshold } \\
(\mu \mathrm{m})\end{array}$ & $\begin{array}{c}\text { Nozzle spray } \\
\text { angle } \\
(\mathrm{deg})\end{array}$ & $\begin{array}{c}\text { Nominal rated } \\
\text { flow rate }^{\mathrm{a}} \\
\left(\mathrm{L} \mathrm{min}^{-1}\right)\end{array}$ & $\begin{array}{c}\text { Reference } \\
\text { flow rate } \\
\left(\mathrm{L} \mathrm{min}^{-1}\right)\end{array}$ & $\begin{array}{c}\text { Reference } \\
\text { operating pressure } \\
(\mathrm{kPa})\end{array}$ \\
\hline $\mathrm{VF} / \mathrm{F}$ & $<153$ & 110 & 0.38 & 0.48 & 440 \\
$\mathrm{~F} / \mathrm{M}$ & $154-241$ & 110 & 1.14 & 1.18 & 300 \\
$\mathrm{M} / \mathrm{C}$ & $242-358$ & 110 & 2.27 & 1.93 & 200 \\
$\mathrm{C} / \mathrm{VC}$ & $359-451$ & 80 & 3.03 & 2.88 & 250 \\
$\mathrm{VC} / \mathrm{XC}$ & $452-740$ & 65 & 3.78 & 3.22 & 200 \\
\hline
\end{tabular}

${ }^{\mathrm{a}}$ Nominal rated flow rate is at $280 \mathrm{kPa}$ and is for nozzle size selection only.

\footnotetext{
Manuscript received September 29, 2008; accepted for publication April 6, 2009; published online June 2009.

${ }^{1}$ University of Nebraska WCREC, 402 West State Farm Road, North Platte, NE 69101, e-mail: rklein1@unl.edu
} 


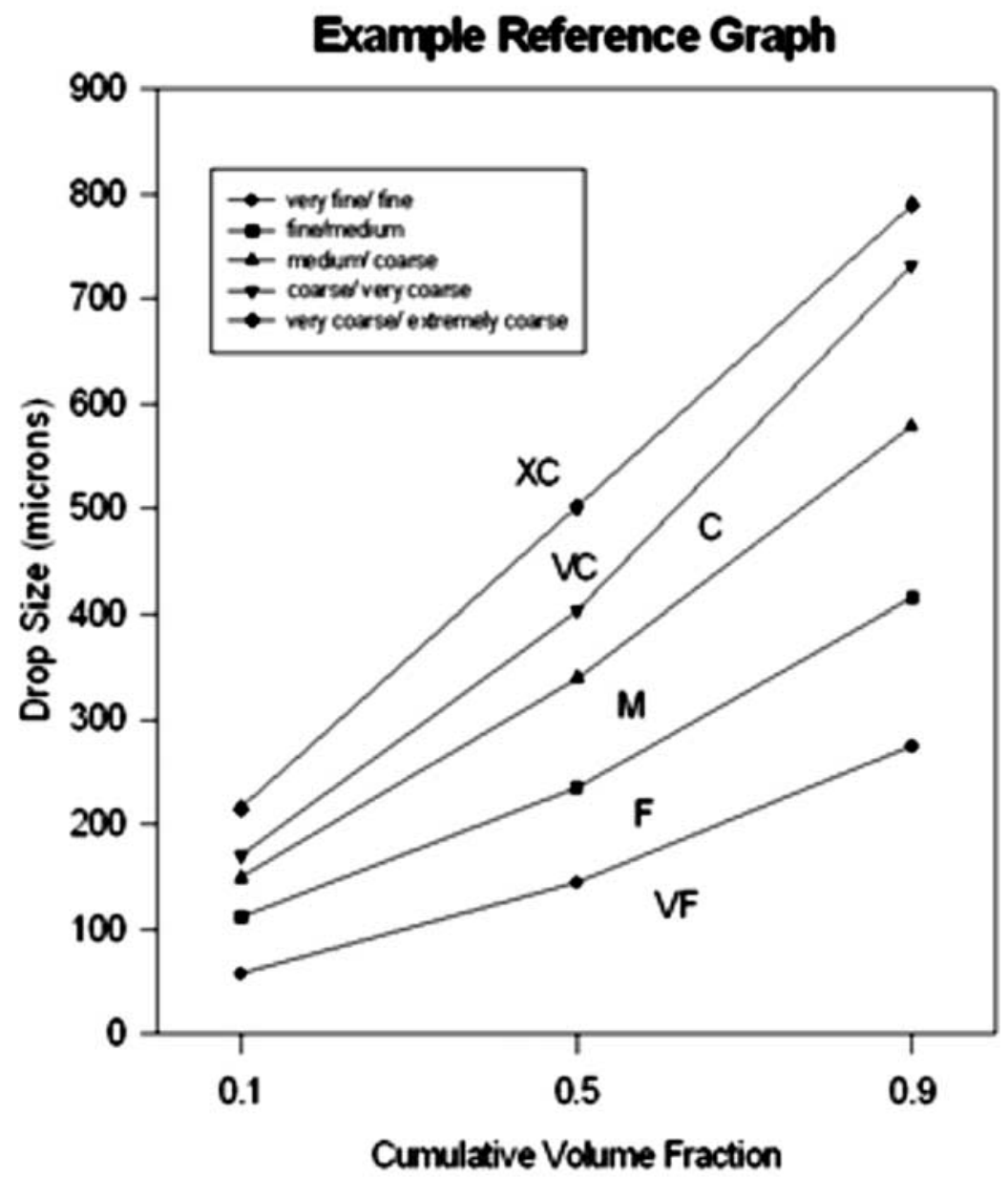

FIG. 1-Sample reference graph developed from measurements averaged from three types of laser instruments.

ence graph developed from measurements averaged from three types of laser instruments is shown in Fig. 1.

Spray droplet size has been shown to be affected by adjuvants that are included in the spray solution. Jones et al. [2] found that polysaccharide adjuvants resulted in a reduction in fine droplets $(<141 \mu \mathrm{m})$ and an increase in volume median diameter (VMD) when applied with glyphosate. Additionally, Prokop and Kejklicek [3] found that the viscosity, surface tension, and density of the spray solution change with the ingredients that are included in the solution. Bouse et al. [4] also found that mixing pesticides and adjuvants can affect the droplet size for the same reasons.

Nozzle tip design can also have an effect on droplet sizes because of the differing ways nozzles produce drops. Nozzles usually have either one or two orifices where spray solution is forced out of the nozzle by pressure. The solution will leave the orifice as a sheet or a thin stream. Droplets from nozzles such as the extended range flat fan and preorifice flat fan will form from the sheet or stream because of a stretching or slicing force. Droplets from air induction nozzles are formed from first directing a stream of spray solution across a gap and then directing it against an angled surface [5]. The objective of the studies conducted was to examine the effects of several adjuvants and pesticide formulations on spray droplet size with several commonly used nozzles. Utilizing common nozzles, pesticides, and adjuvants in the studies allows for greater understanding of what factors have the greatest impact on spray droplet size in current field practices.

\section{Materials and Methods}

A Sympatec Helos/KF particle analyzer is being used at the West Central Research and Extension Center in North Platte, NE to evaluate droplet sizes produced by nozzle tips. The analyzer uses laser diffraction 
TABLE 2-List of adjuvants used in droplet size analysis.

\begin{tabular}{|c|c|c|}
\hline Adjuvant & Composition & Produced By \\
\hline Array & $\begin{array}{l}\text { Deposition/retention agent; a proprietary blend of } \\
\text { ammonium salts plus modified elasto DR } 2000 \\
\text { polymer and antifoaming agent }\end{array}$ & Intec Agro Products, LLC \\
\hline In-Place & $\begin{array}{c}\text { Deposition/retention agent; modified vegetable oil, } \\
\text { aliphatic mineral oil, amine salts of organic acids, } \\
\text { and aromatic acid }\end{array}$ & Wilbur-Ellis \\
\hline Interlock & $\begin{array}{c}\text { Deposition/retention agent; modified vegetable oil } \\
\text { and emulsifiers }\end{array}$ & Agrisolutions \\
\hline Thrust & $\begin{array}{l}\text { Deposition/retention agent; proprietary blend of } \\
\text { milled AMS, drift reduction/deposition polymers, } \\
\text { and antifoaming agents }\end{array}$ & Loveland Products, Inc. \\
\hline Prime Oil (COC) & $\begin{array}{c}\text { Paraffin based petroleum oil, fatty acid esters, and } \\
\text { derivates }\end{array}$ & Agrisolutions \\
\hline Preference (NIS) & $\begin{array}{l}\text { A proprietary surfactant based mixture which } \\
\text { contains ethylene oxide and dioxane }\end{array}$ & Agrisolutions \\
\hline
\end{tabular}

to determine the droplet size distribution. The width of the spray plume is analyzed by moving the nozzle across the laser by means of a linear actuator. Droplet characteristics such as VMD and percentage of the spray volume $210 \mu \mathrm{m}$ and less (droplets most prone to drift) can be obtained. Each treatment was replicated three times. Spray solution was run through a nozzle only once.

In the first trial, adjuvants were analyzed with a potassium salt of glyphosate (Roundup WeatherMax®, Monsanto) at $0.87 \mathrm{~kg} \mathrm{ae} \mathrm{ha}^{-1}$. Adjuvants that were used and their formulations are listed in Table 2. The adjuvant rates were Array (polymer adjuvant) at $1 \mathrm{~kg} 100 \mathrm{~L}^{-1}$, In-Place (vegetable oil adjuvant) at $0.4 \mathrm{~L} \mathrm{ha}^{-1}$, and Interlock (vegetable oil adjuvant) at $0.29 \mathrm{~L} \mathrm{ha}^{-1}$. Ammonium sulfate (AMS) at $2 \% \mathrm{w} / \mathrm{w}$ was included in all treatments. The nozzle tips evaluated include extended range flat fan size 11005, preorifice flat fan 1 size 11005, preorifice flat fan 2 size 2.5, air induction flat fan size 11005, and air induction extended range flat fan size 11005 . All nozzles were used at $280 \mathrm{kPa}$ at which $0.032 \mathrm{~L} \mathrm{~s}^{-1}$ of solution was delivered. Spray application volume was $94 \mathrm{~L} \mathrm{ha}^{-1}$. This spray application volume contained the concentration of herbicide and adjuvants to achieve the stated rates per hectare.

A second study was conducted to evaluate the droplet size of the extended range flat fan size 11005 at $280 \mathrm{kPa}$, preorifice flat fan size 11005 at $280 \mathrm{kPa}$, and an air induction flat fan size 11004 at $450 \mathrm{kPa}$. Treatments included sodium salt of diflufenzopyr+dicamba at $0.35 \mathrm{~kg}$ ai/ha with nonionic surfactant (NIS) at $0.25 \% \mathrm{v} / \mathrm{v}$, or crop oil concentrate (COC) at $2.3 \mathrm{~L} \mathrm{ha}^{-1}$. The adjuvants used and their rates were Array (polymer adjuvant) at $1 \mathrm{~kg} 100 \mathrm{~L}^{-1}$, Interlock (vegetable oil adjuvant) at $0.29 \mathrm{~L} \mathrm{ha}^{-1}$, and Thrust (polymer adjuvant) at $1 \mathrm{~kg} 100 \mathrm{~L}^{-1}$, and are also described in Table 2. Spray application volume was $140 \mathrm{~L} \mathrm{ha}^{-1}$.

A third trial evaluated three fungicides, propiconazole (emulsifiable concentrate formulation) at $0.25 \mathrm{~kg} \mathrm{ha}^{-1}$, azoxystrobin (flowable formulation) at $0.38 \mathrm{ha}^{-1}$, and propiconazole + azoxystrobin (suspoemulsion formulation) at $0.30 \mathrm{~kg} \mathrm{ha}^{-1}$. Treatments consisting of three different spray volumes with each fungicide were compared to spraying water alone. Spray volumes used for the fungicide trial were 23, 47, and $94 \mathrm{~L} \mathrm{ha}^{-1}$. Nozzles used were an extended range flat fan size 11003 at $200 \mathrm{kPa}$ and an extended range flat fan size 11005 at $400 \mathrm{kPa}$.

For all three trials, data were subjected to analysis of variance (ANOVA) using STATISTIX 8.1 and means were separated using least significant differences (LSD) at $\alpha=0.05$.

\section{Results and Discussion}

In the first trial, the addition of potassium salt of glyphosate+AMS reduced VMD when compared to the water alone treatment for each of the five nozzles (Table 3). With the extended range flat fan nozzle, the addition of Array, In-Place, and Interlock all increased VMD when compared to the glyphosate+AMS and water treatments. In-Place increased VMD to a greater extent than did Array. For the preorifice flat fan 1 nozzle, the addition of Array increased VMD to a point significantly greater than just water. Adding In-Place or Interlock both decreased VMD compared to glyphosate+AMS. The adjuvants had similar 
TABLE 3-Spray droplet sizes of glyphosate spray solutions (94 L ha $\mathrm{ha}^{-1}$ spray volume) applied through five different nozzles at 280 kPa. [Sharing common postscript within a column is not significantly different (LSD test, alpha $=0.05$.]

\begin{tabular}{|c|c|c|c|c|c|c|c|c|c|c|}
\hline \multirow[b]{2}{*}{ Treatment $^{\mathrm{a}}$} & \multicolumn{2}{|c|}{$\begin{array}{c}\text { Extended range } \\
\text { flat fan }\end{array}$} & \multicolumn{2}{|c|}{ Preorifice flat fan 1} & \multicolumn{2}{|c|}{ Preorifice flat fan 2} & \multicolumn{2}{|c|}{ Air induction flat fan } & \multicolumn{2}{|c|}{$\begin{array}{l}\text { Extended range } \\
\text { air induction }\end{array}$} \\
\hline & $\begin{array}{l}\mathrm{VMD}^{\mathrm{b}} \\
(\mu \mathrm{m})\end{array}$ & $\begin{array}{c}\text { Percent }^{\mathrm{c}} \\
(<210 \mu \mathrm{m})\end{array}$ & $\begin{array}{l}\text { VMD } \\
(\mu \mathrm{m})\end{array}$ & $\begin{array}{c}\text { Percent } \\
(<210 \mu \mathrm{m})\end{array}$ & $\begin{array}{l}\text { VMD } \\
(\mu \mathrm{m})\end{array}$ & $\begin{array}{c}\text { Percent } \\
(<210 \mu \mathrm{m})\end{array}$ & $\begin{array}{l}\text { VMD } \\
(\mu \mathrm{m})\end{array}$ & $\begin{array}{c}\text { Percent } \\
(<210 \mu \mathrm{m})\end{array}$ & $\begin{array}{l}\text { VMD } \\
(\mu \mathrm{m})\end{array}$ & $\begin{array}{c}\text { Percent } \\
(<210 \mu \mathrm{m})\end{array}$ \\
\hline Water & $275 \mathrm{c}$ & $33.2 \mathrm{~b}$ & $410 \mathrm{~b}$ & $16.6 \mathrm{c}$ & $453 \mathrm{~b}$ & $15.9 \mathrm{c}$ & $580 \mathrm{a}$ & $6.6 \mathrm{c}$ & 487 & $8.6 \mathrm{c}$ \\
\hline None & $223 \mathrm{~d}$ & $46.4 \mathrm{a}$ & $374 \mathrm{c}$ & $20.7 \mathrm{~b}$ & $397 \mathrm{c}$ & $21.7 \mathrm{~b}$ & $415 \mathrm{c}$ & $17.7 \mathrm{~b}$ & 311 & $26.7 \mathrm{a}$ \\
\hline In-Place $\mathrm{e}^{\mathrm{e}}$ & 298 a & $23.4 \mathrm{c}$ & $323 \mathrm{~d}$ & $23.3 \mathrm{a}$ & $351 \mathrm{~d}$ & $23.9 \mathrm{a}$ & $530 \mathrm{~b}$ & $4.3 \mathrm{~d}$ & 471 & $6.3 \mathrm{~d}$ \\
\hline Interlock $\mathrm{k}^{\mathrm{f}}$ & $294 \mathrm{ab}$ & $24.0 \mathrm{c}$ & $322 \mathrm{~d}$ & $23.5 \mathrm{a}$ & $359 \mathrm{~d}$ & $22.9 \mathrm{ab}$ & $539 \mathrm{~b}$ & $4.0 \mathrm{~d}$ & 467 & $6.3 \mathrm{~d}$ \\
\hline
\end{tabular}

${ }^{\mathrm{a}}$ All treatments, except water, contained potassium salt of glyphosate at $0.351 \mathrm{~kg} \mathrm{ae} \mathrm{ha}^{-1}$ and AMS at $2 \%$ w:w.

${ }^{\mathrm{b}}$ Volume median diameter.

${ }^{\mathrm{c}}$ Percent of spray volume less than $210 \mu \mathrm{m}$.

${ }^{\mathrm{d}}$ Array rate equals $1 \mathrm{~kg} 100 \mathrm{~L}^{-1}$.

${ }^{\mathrm{e}}$ In-Place rate equals $0.4 \mathrm{~L} \mathrm{ha}^{-1}$.

${ }^{\mathrm{f}}$ Interlock rate equals $0.29 \mathrm{~L} \mathrm{ha}^{-1}$.

effects on the preorifice flat fan 2 nozzle as the preorifice flat fan 1, with Array increasing VMD above that of water. With the air induction nozzle, Array significantly reduced VMD. This could be due to the two orifice nozzle designs of the air induction nozzle. The air induction nozzle type uses a preorifice to measure the solution, then mixes it with air and expels the solution through a second larger orifice. Research conducted by Womac [6] concluded that the difference between the two orifice diameters of flooding nozzles was the most important factor in the nozzle droplet size spectra. The two orifice designs of the air induction may have a similar effect, with Array reducing VMD for this nozzle and not the others. In-Place and Interlock both increased VMD when compared to glyphosate+ AMS but not to the point of the water treatment. With the air induction extended range nozzle Array, In-Place, and Interlock all increased VMD compared to glyphosate+AMS. In-Place and Interlock increased VMD greater than Array. In most aspects, the air induction extended range nozzle is an improvement over the extended range, producing a larger droplet overall and smaller percentage of fine droplets.

The percentage of the spray volume $210 \mu \mathrm{m}$ and less (to be referred to as "fines") increased with glyphosate as compared to just water for all five nozzle types. As with VMD, the adjuvants also had differing effects with each nozzle. In-Place and Interlock reduced the percentage of fines, decreasing it to a level lower than the water alone treatment with the extended range, air induction, and air induction extended range nozzles. With both preorifice nozzles, In-Place and Interlock both increased the percentage of fines when compared to glyphosate alone. Array reduced fines with the preorifice nozzles to less than water alone. Array also reduced fines with the extended range and air induction extended range nozzles, with the extended range equaling water alone. The air induction saw an increase in fines with the addition of Array, while the extended range nozzle saw a reduction in fines with Array to the point of water alone. Being that the air induction extended range is a hybrid of the extended range and air induction nozzles, results show characteristics of both nozzles.

Previous research by Womac et al. [7] was conducted with adjuvants. This and other research were also summarized by Spanoghe et al. [8]. Vegetable oils tended to increase VMD with flat fan nozzles and preorifice flat fan nozzles, and show a small decrease with air induction nozzles. In this study, the extended range flat fan nozzle similarly raised VMD when a vegetable oil adjuvant was added to the glyphosate spray mixture. The preorifice flat fan nozzles lowered VMD with glyphosate in the mixture, suggesting that the glyphosate may have had an effect on how the oil adjuvants respond with this type of nozzle. The air induction nozzle responded with a raised VMD, which differed from previous research, and once again glyphosate in the mixture may be influencing how the nozzle reacts. The polymer adjuvant responded similarly to previously conducted studies, with VMD being reduced with the air induction nozzle and raised with the extended rage flat fan, preorifice flat fan, and the extended range air induction nozzle.

Results of the second trial, diflufenzopyr + dicamba with the addition of a nonionic surfactant or crop oil concentrate, are shown in Table 4. For the extended range flat fan nozzle, the addition of COC or NIS increased VMD when compared to the diflufenzopyr+dicamba alone treatment. Adding Interlock to either the COC or NIS solutions had no effect. Array and Thrust lowered VMD when added to either COC or 
TABLE 4-Spray droplet sizes of several spray solutions (94 L ha $\mathrm{h}^{-1}$ spray volume) applied through three nozzles. [Sharing common postscript within a column is not significantly different (LSD test, alpha $=0.05)$.]

\begin{tabular}{|c|c|c|c|c|c|c|}
\hline \multirow[b]{2}{*}{ Treatment $^{\mathrm{c}}$} & \multicolumn{2}{|c|}{$\begin{array}{l}\text { Extended range flat } \\
\text { fan size } 11005^{\mathrm{a}}\end{array}$} & \multicolumn{2}{|c|}{$\begin{array}{l}\text { Preorifice flat } \\
\text { fan size } 11005^{\mathrm{a}}\end{array}$} & \multicolumn{2}{|c|}{$\begin{array}{l}\text { Air induction } \\
\text { size } 11004^{b}\end{array}$} \\
\hline & $\begin{array}{l}V_{M D^{d}} \\
(\mu \mathrm{m})\end{array}$ & $\begin{array}{c}\text { Percent }^{\mathrm{e}} \\
(<210 \mu \mathrm{m})\end{array}$ & $\begin{array}{l}\text { VMD } \\
(\mu \mathrm{m}) \\
\end{array}$ & $\begin{array}{c}\text { Percent } \\
(<210 \mu \mathrm{m})\end{array}$ & $\begin{array}{l}\text { VMD } \\
(\mu \mathrm{m})\end{array}$ & $\begin{array}{c}\text { Percent } \\
(<210 \mu \mathrm{m})\end{array}$ \\
\hline Diflufenzopyr+dicamba & $296 \mathrm{~b}$ & $26.7 \mathrm{c}$ & $393 \mathrm{~d}$ & $17.5 \mathrm{f}$ & $440 \mathrm{~d}$ & $10.3 \mathrm{c}$ \\
\hline NIS ${ }^{f}$ & $334 \mathrm{a}$ & $16.0 \mathrm{~d}$ & $353 \mathrm{e}$ & $19.9 \mathrm{e}$ & $454 \mathrm{c}$ & $8.4 \mathrm{de}$ \\
\hline $\mathrm{COC}^{\mathrm{g}}$ & $333 \mathrm{a}$ & $16.0 \mathrm{~d}$ & $336 \mathrm{f}$ & $21.6 \mathrm{~d}$ & $449 \mathrm{c}$ & $8.3 \mathrm{e}$ \\
\hline Array $^{\text {h }}+$ NIS & $295 \mathrm{~b}$ & $33.3 \mathrm{~b}$ & $470 \mathrm{a}$ & $12.0 \mathrm{i}$ & $471 \mathrm{a}$ & $13.9 \mathrm{a}$ \\
\hline Array $+\mathrm{COC}$ & $281 \mathrm{c}$ & $35.9 \mathrm{a}$ & $456 \mathrm{~b}$ & $13.2 \mathrm{~h}$ & $463 \mathrm{~b}$ & $13.8 \mathrm{a}$ \\
\hline Thrust $^{\mathrm{h}}+\mathrm{NIS}$ & $275 \mathrm{~cd}$ & $34.9 \mathrm{ab}$ & $405 \mathrm{c}$ & $14.1 \mathrm{~h}$ & $452 \mathrm{c}$ & $10.7 \mathrm{~b}$ \\
\hline Thrust +COC & $267 \mathrm{~d}$ & $35.4 \mathrm{a}$ & $383 \mathrm{~d}$ & $16.5 \mathrm{~g}$ & $443 \mathrm{~d}$ & $10.5 \mathrm{bc}$ \\
\hline Interlock $^{\mathrm{i}}+\mathrm{NIS}$ & $342 \mathrm{a}$ & $15.5 \mathrm{~d}$ & $321 \mathrm{gh}$ & $24.6 \mathrm{~b}$ & $443 \mathrm{~d}$ & $8.7 \mathrm{~d}$ \\
\hline Interlock $+\mathrm{COC}$ & $340 \mathrm{a}$ & $15.1 \mathrm{~d}$ & $312 \mathrm{~h}$ & $25.8 \mathrm{a}$ & $440 \mathrm{~d}$ & $8.6 \mathrm{~d}$ \\
\hline \multicolumn{7}{|c|}{${ }^{\mathrm{a} N o z z l e}$ pressure equals $280 \mathrm{kPa}$. } \\
\hline \multicolumn{7}{|c|}{${ }^{\mathrm{c}}$ Each treatment contained diflufenzopyr + dicamba at $0.35 \mathrm{~kg} \mathrm{ai} \mathrm{ha}^{-1}$. } \\
\hline \multicolumn{7}{|c|}{${ }^{\mathrm{d}}$ Volume median diameter. } \\
\hline \multicolumn{7}{|c|}{${ }^{\mathrm{e}}$ Percent of spray volume less than $210 \mu \mathrm{m}$. } \\
\hline \multicolumn{7}{|c|}{${ }^{\mathrm{f}} \mathrm{NIS}=$ Nonionic surfactant, product rate equals $0.25 \%$ v:v. } \\
\hline \multicolumn{7}{|c|}{${ }^{\mathrm{g}} \mathrm{COC}=$ Crop oil concentrate, product rate equals $2.34 \mathrm{~L} \mathrm{ha}^{-1}$. } \\
\hline \multicolumn{7}{|c|}{${ }^{\mathrm{h}}$ Product rate equals $1 \mathrm{~kg} 100 \mathrm{~L}^{-1}$. } \\
\hline interlock rate equals $0.29 \mathrm{I}$ & $\mathrm{ha}^{-1}$. & & & & & \\
\hline
\end{tabular}

NIS. With Array+NIS, VMD was lowered to the level of the diflufenzopyr+dicamba alone treatment. Array + COC and both Thrust treatments lowered VMD further. VMD ranged from 342 to $267 \mu \mathrm{m}$, a difference of 75 . The percentage of the spray volume less than $210 \mu \mathrm{m}$ responded accordingly, with NIS, $\mathrm{COC}$, and Interlock treatments all reducing the percentage when compared to the diflufenzopyr + dicamba alone treatment. The Array and Thrust treatments all increased the percentage.

For the preorifice flat fan nozzle, the addition of COC or NIS to diflufenzopyr+dicamba lowered VMD, with COC lowering to a greater extent. Adding Array or Thrust to the spray solution increased VMD, with Array raising it by greater than $100 \mu \mathrm{m}$. Interlock significantly lowered VMD when included with either COC or NIS, with COC being lower. When comparing COC with NIS, the treatments with COC resulted in a lower VMD, with the exception of Interlock. VMD ranged from 470 to $312 \mu \mathrm{m}$, a difference of 158 . The percentage of the spray volume less than $210 \mu \mathrm{m}$ results differed accordingly. COC and NIS both raised this percentage when compared to the diflufenzopyr+dicamba treatment. Array and Thrust both lowered the percentage while Interlock increased. As with VMD, treatments with COC had a greater percentage of fines than the corresponding NIS treatment with this nozzle.

For the air induction nozzle, adding NIS or COC to diflufenzopyr+dicamba increased VMD. Adding Array to the solution increased VMD for both NIS and COC. Thrust had no effect with NIS but lowered VMD with COC. Interlock lowered VMD with COC or NIS in the solution. The range in VMD was $31 \mu \mathrm{m}(471-440 \mu \mathrm{m})$, which is much smaller than the other nozzles. Adding COC or NIS resulted in a decrease in the percentage of the spray solution $210 \mu \mathrm{m}$ and less. Adding Interlock did not change this percentage but Array and Thrust resulted in more fine droplets. Array had more fine drops than the other treatments.

With the adjuvants, results varied by nozzle. COC and NIS increased VMD with the extended range and air induction nozzles but decreased with the preorifice nozzle. Array increased VMD for the preorifice and air induction nozzles but decreased for the extended range. Thrust had similar effects with each nozzle as Array on a smaller scale. Interlock had no effect on the extended range nozzle but decreased VMD for the preorifice and to a lesser degree the air induction. It also had little effect on the percentage less than $210 \mu \mathrm{m}$ with the air induction and extended range but further increased with the preorifice nozzle. In general, the extended range nozzle produced the smallest VMD and also the greatest portion of the spray volume under $210 \mu \mathrm{m}$. The preorifice nozzle was the next largest, followed by air induction nozzle. The addition of a specific adjuvant can change the relative rankings of the nozzles. 
TABLE 5-VMD and percent of spray volume less than $210 \mu \mathrm{m}$ of propicanozole, azoxystrobin, and propicanozole plus azoxystrobin at three spray volumes. [Sharing common postscripts (abcd) within a column and nozzle is not significantly different (LSD test, $\alpha$ $=0.05$ ); sharing common postscripts (xyz) within a row are not significantly different (LSD test, $\alpha=0.05)$.]

\begin{tabular}{|c|c|c|c|c|c|c|c|}
\hline \multirow[b]{3}{*}{ Nozzle } & \multirow[b]{3}{*}{ Fungicide } & \multicolumn{3}{|c|}{$\mathrm{VMD}^{\mathrm{a}}$} & \multicolumn{3}{|c|}{$\begin{array}{l}\text { Percentage less } \\
\text { than } 210 \mu \mathrm{m}^{\mathrm{b}}\end{array}$} \\
\hline & & \multicolumn{3}{|c|}{ Spray volume $\mathrm{L} \mathrm{ha}^{-1}$} & \multicolumn{3}{|c|}{ Spray volume $\mathrm{L} \mathrm{ha}^{-1}$} \\
\hline & & 23 & $\begin{array}{c}47 \\
(\mu \mathrm{m})\end{array}$ & 94 & 23 & $\begin{array}{l}47 \\
(\%)\end{array}$ & 94 \\
\hline \multirow[t]{4}{*}{ Nozzle $11003^{\mathrm{c}}$} & None & $253 \mathrm{c}$ & $253 \mathrm{c}$ & $253 \mathrm{c}$ & $36.13 \mathrm{~b}$ & $36.13 \mathrm{a}$ & $36.13 \mathrm{a}$ \\
\hline & Propicanozole $^{\mathrm{d}}$ & 300 a (y) & 315 a $(x)$ & 317 a $(x)$ & $21.28 \mathrm{~d}(\mathrm{x})$ & $18.21 \mathrm{c}(\mathrm{y})$ & $16.98 \mathrm{~d}(\mathrm{z})$ \\
\hline & Azoxystrobin $^{\mathrm{e}}$ & $265 \mathrm{~b}(\mathrm{x})$ & $257 \mathrm{~b}(\mathrm{y})$ & $257 \mathrm{c}(\mathrm{y})$ & $33.34 \mathrm{c}(\mathrm{y})$ & $34.87 \mathrm{~b}(\mathrm{x})$ & $34.78 \mathrm{~b}(\mathrm{x})$ \\
\hline & Propicanozole +azoxystrobin ${ }^{\mathrm{f}}$ & $240 \mathrm{~d}(\mathrm{z})$ & $251 \mathrm{c}(\mathrm{y})$ & $265 \mathrm{~b}(\mathrm{x})$ & 40.10 a $(\mathrm{x})$ & 36.75 a $(y)$ & $31.76 \mathrm{c}(\mathrm{z})$ \\
\hline \multirow[t]{4}{*}{ Nozzle $11005^{\mathrm{g}}$} & None & $245 \mathrm{~b}$ & $245 \mathrm{c}$ & $245 \mathrm{c}$ & 39.63 & 39.63 & 39.63 \\
\hline & Propicanozole & 269 a $(y)$ & 279 a $(x)$ & 279 a $(x)$ & $30.69 \mathrm{c}(\mathrm{x})$ & $27.91 \mathrm{c}(\mathrm{y})$ & $26.53 \mathrm{~d}(\mathrm{z})$ \\
\hline & Azoxystrobin & 270 a $(x)$ & $261 \mathrm{~b}(\mathrm{xy})$ & $253 \mathrm{c}(\mathrm{y})$ & $33.62 \mathrm{~b}(\mathrm{y})$ & $35.32 \mathrm{~b}(\mathrm{y})$ & $37.38 \mathrm{~b}(\mathrm{x})$ \\
\hline & Propicanozole + azoxystrobin & $241 \mathrm{~b}(\mathrm{y})$ & $242 \mathrm{c}(\mathrm{y})$ & $265 \mathrm{~b}(\mathrm{x})$ & $40.50 \mathrm{a}(\mathrm{x})$ & 40.19 a $(\mathrm{x})$ & $32.89 \mathrm{c}(\mathrm{y})$ \\
\hline
\end{tabular}

\footnotetext{
${ }^{\mathrm{a}}$ Volume median diameter.

${ }^{\mathrm{b}}$ Percentage of spray volume less than $210 \mu \mathrm{m}$.

${ }^{c}$ Extended range flat fan nozzle size 11003 at $200 \mathrm{kPa}$.

${ }^{\mathrm{d}}$ Propicanozole rate equals $0.25 \mathrm{~kg} \mathrm{ha}^{-1}$.

${ }^{\mathrm{e}}$ Azoxystrobin rate equals $0.38 \mathrm{~kg} \mathrm{ha}^{-1}$.

${ }^{\mathrm{f}}$ Propicanozole plus azoxystrobin rate equals $0.30 \mathrm{~kg} \mathrm{ha}^{-1}$.

${ }^{\mathrm{g}}$ Extended range flat fan nozzle size 11005 at $400 \mathrm{kPa}$.
}

In this trial, the polymer adjuvants reduced VMD with the extended range flat fan nozzle, which is in contrast with previous studies of Spanoghe et al. [8]. This may be due to the presence of other ingredients in the spray solution such as NIS, COC, and the diflufenzopyr+dicamba active ingredients. The modified vegetable oil adjuvant responded similarly to previous studies with this nozzle. The preorifice flat fan nozzle responded similarly (raising VMD) for the polymer adjuvants while reacting differently for the vegetable oil adjuvant. The air induction nozzle tended to respond similarly as in the previous research, with one polymer adjuvant raising VMD, the other equaling or slight lowering. The vegetable oil adjuvant lowered VMD, as previously been shown with that adjuvant type. It appears as though the preorifice nozzles are reacting differently with vegetable oil adjuvants in combination with other active ingredientsglyphosate or diflufenzopyr+dicamba.

Results of the third trial with fungicides are in Table 5. With the 11003 extended range flat fan nozzle, propicanozole increased VMD compared to water at all three spray volumes, with its effect increasing as spray volume increased. Azoxystrobin also increased VMD though not to the level of propicanozole. The effect was greatest at $23 \mathrm{~L} \mathrm{ha}^{-1}$. The propicanozole plus azoxystrobin treatment lowered VMD at the $23 \mathrm{~L} \mathrm{ha}^{-1}$ spray volume, had no effect at $47 \mathrm{~L} \mathrm{ha}^{-1}$, and increased at $94 \mathrm{~L} \mathrm{ha}^{-1}$. Treatment rankings were very similar with the percentage of spray volume less than $210 \mu \mathrm{m}$ with the 11003 extended range flat fan nozzle. Propicanozole lowered the percentage at all three spray volumes and the difference was greatest at $94 \mathrm{~L} \mathrm{ha}^{-1}$. Azoxystrobin slightly lowered the percentage in all three spray volumes, with the greatest effect at $94 \mathrm{~L} \mathrm{ha}^{-1}$. Propicanozole plus azoxystrobin raised the percentage at $23 \mathrm{~L} \mathrm{ha}^{-1}$, equalled at $47 \mathrm{~L} \mathrm{ha}^{-1}$, and lowered at $94 \mathrm{~L} \mathrm{ha}^{-1}$.

With the 11005 extended range flat fan nozzle, treatment differences were similar at the 47 and $94 \mathrm{~L} \mathrm{ha}^{-1}$ spray volumes for VMD. At the $23 \mathrm{~L} \mathrm{ha}^{-1}$ spray volume, propicanozole and azoxystrobin were equal and both increased VMD when compared to water. The propicanozole plus azoxystrobin treatment had no effect, as opposed to lowering VMD with the 11003 nozzle. For the percentage less than $210 \mu \mathrm{m}$, propicanozole lowered at all three spray volumes, with the largest effect at $94 \mathrm{~L} \mathrm{ha}^{-1}$. Azoxystrobin also lowered the percentage at all three volumes, though not to the degree of propicanozole. Azoxystrobin had the greatest reduction at $23 \mathrm{~L} \mathrm{ha}^{-1}$ spray volume. Propicanozole plus azoxystrobin had no effect at 23 and $47 \mathrm{~L} \mathrm{ha}^{-1}$ volumes and decreased at 94 . These are all similar to the effects on VMD for this nozzle.

Analysis of the three spray volumes is also in Table 5. With the 11003 extended range flat fan nozzle, propicanozole increased VMD going from 23 to 47, no change from 47 to 94. Azoxystrobin's effect was opposite, with the 23 spray volume providing the largest VMD. The propicanozole plus azoxystrobin 
treatment was similar to propicanozole alone, with each spray volume being different $(94>47>23)$. For the 11005 nozzle, results were similar, with the exceptions of the 23 and 47 spray volumes being equal for both the azoxystrobin and propicanozole plus azoxystrobin treatments. For the percentage of the spray volume less than $210 \mu \mathrm{m}$, propicanozole decreased as the spray volume increased for both nozzles. Azoxystrobin had the opposite effect on this variable as well, with the $94 \mathrm{~L} \mathrm{ha}^{-1}$ volume providing the greatest percentage. The propicanozole plus azoxystrobin treatment acted similarly to propicanozole alone, with the $94 \mathrm{~L} \mathrm{ha}^{-1}$ spray volume having the lowest percentage.

The propicanozole alone treatment is an emulsifiable concentrate, while azoxystrobin is a flowable, and propicanozole plus azoxystrobin is a suspoemulsion. The propicanozole treatment behaves in such a way that the lower spray volumes - those that have a higher concentration of product - have a smaller effect on VMD and percentage less than $210 \mu \mathrm{m}$. This is similar to the results obtained by Barnett and Matthews [9], who found that adding a codacide oil to a spray mixture decreased the percentage of spray volume less than $100 \mu \mathrm{m}$. Its effect was greater at a lower concentration of the oil in the spray solution. With the fungicide propicanozole, the effect of the product increases as the carrier volume increased, even though the density of the product in the spray solution decreases. Similar effects were seen with the propicanozole plus azoxystrobin treatment. Spanoghe et al. [8] also reviewed studies concerning adjuvant effects and found that vegetable and mineral oil based adjuvants raised VMD when compared to water.

Spray droplet size and distribution are affected by pesticide, spray volume concentration, nozzle tip design, and pressure. Formulations of glyphosate, diflufenzopyr+dicamba, fungicides, and adjuvants showed a direct effect on the droplet size of spray droplets. This is due to changes in the surface tension, viscosity, and density of the solution. Differences in nozzle design also contribute to changes in droplet size. An adjuvant can have opposite effects on spray droplet size with different nozzle designs. Spray volume can also play a role with the effect of pesticide and adjuvant formulations. Care must be taken by the applicator when considering the addition of an adjuvant to the spray solution to avoid unintended consequences, such as increasing the amount of driftable droplets or moving the VMD away from the optimal range desired for a particular spray application.

\section{References}

[1] ASAE, Spray Nozzle Classification by Droplet Spectra, ASAE S572 AUG99, American Society of Agricultural Engineers, St. Joseph, MI, 1999.

[2] Jones, E. J., Hanks, J. E., Wills, G. D., and Mack, R. E., "Effect of Two Polysaccharide Adjuvants on Glyphosate Spray Droplet Size and Efficacy," Weed Technol., Vol. 21, 2007, pp. 171-174.

[3] Prokop, M., and Kejklicek, R., "Effect of Adjuvants on Spray Droplet Size of Water," Research in Agricultural Engineering, Vol. 48, 2002, pp. 144-148.

[4] Bouse, L. F., Kirk, I. W., and Bode, L. E., "Effect of Spray Mixture on Droplet Size," Trans. ASAE, Vol. 33, 1990, pp. 783-788.

[5] The Pesticide Label, The University of Hawaii, Manoa, HI, 2007.

[6] Womac, A. R., "Atomization Characteristics of High-Flow Variable-Orifice Flooding Nozzles," Trans. ASAE, Vol. 44, 2001, pp. 463-471.

[7] Womac, A. R., Goodwin, J. C., and Hart, W. E., "Tip Selection for Precision Application of Herbicides. A Lookup Table of Drop Sizes to Assist in the Selection of Nozzles," Bulletin 695, University of Tennessee Agricultural Experiment Station, Knoxville, TN, 1997.

[8] Spanoghe, P., De Schampheleire, M., Van der Meeren, P., and Steurbaut, W., "Influence of Agricultural Adjuvants on Droplet Spectra," Pest Manage. Sci., Vol. 63, 2007, pp. 4-16.

[9] Barnett, G. S., and Matthews, G. A., "Effect of Different Fan Nozzles and Spray Liquids on Droplet Spectra with Special Reference to Drift Control," Proceedings of the International Pest Control, May/June 1992 (unpublished), pp. 81-85. 